УДК $81,11: 811.17 .3$

DOI: 10.17277/voprosy.2015.02.pp.132-137

\title{
ELIMINATION OF CROSS CULTURAL ASYMMETRY: COGNITIVE AND TRANSCORDING ASPECTS
}

\author{
V. A. Lazarev, M. V. Laskova, M. S. Medvedeva \\ South Federal University, Rostov-on-Don \\ Reviewed by Doctor of Philology, Professor E. G. Kulikova
}

Keywords: cultural lacuna; gentrification; nationally-marked vocabulary; non-equivalent vocabulary; structural exotism; timenon-equivalent terms; transcription/transliteration.

\begin{abstract}
The authors make an attempt to find out the ways to alleviate intercultural communication barriers and eliminate inconsistencies in the translation of literary texts. The emphasis is put on achieving the equivalence of secondary texts complicated by cognitive gaps.
\end{abstract}

Nationally-marked vocabulary often becomes a tool in the hands of a writer, as it can help to make the narration brighter, add national color or cut down the temporal distance between the reader and what is happening in the novel. In its turn, this gives additional difficulties for the translator. But, the latter must not only acquaint the reader with a particular household, cooking or folk concept that can be done with the help of descriptive translation, but it also allows to recreate the pragmatic potential, the set of connotative and emotive effects, which a priori are perceived and treated by native speaker's cultural code.

As a material for the translation and analysis, we have chosen the novel "Freedom" by the contemporary American writer Jonathan Franzen. Despite the low popularity with Russian readers, the writer's creative work is widely discussed in the American press, including critics. His penultimate novel "Corrections" was awarded the Pulitzer Prize. In general, the novels of D. Franzen are marked by enormous scale of what is happening in space and time, a thorough portrayal of characters, life, family life, and the description of stereotypes across generations and even the whole history. It triggers to compare him with Leo Tolstoy. To capture a true picture of an ordinary

Лазарев Владимир Александрович - доктор филологических наук, профессор кафедры перевода и информационных технологий в лингвистике, e-mail: Perevod.ros@rambler.ru; Ласкова Марина Васильевна - доктор филологических наук, профессор, заведующая кафедрой перевода и информационных технологий в лингвистике; Медведева Марина Сергеевна - аспирант кафедры перевода и информационных технологий в лингвистике, ФГАОУ ВПО «Южный федеральный университет», г. Ростов-на-Дону. 
American family life would be impossible without color, nationally-marked vocabulary. The adequate perception of a foreign recipient can be possible on condition that the translation of American cultural concepts is correct as they make up equivalent a large part of his peculiarity.

Analyzing the text of the novel "Freedom", you can find a large number of units that fall under the category of non-equivalent vocabulary - anthroponyms, geographic names, names of institutions, companies, specific rituals, household items, etc. Such vocabulary is usually translated with the help of transcription, calques, explication of concepts, linguistics comments, compensations and some other mixed-translation techniques. Let's consider a few examples of authentic translation given by us:

Patty and Walter Berglund were the new pioneers of old St. Paul-the gentrifiers, the hands-on parents, the avant-garde of the Whole Foods generation. (Пэтти и Уолтер Бэрглунд стали еще одними первопоселенцами Сэнт-Пола, участвовавшими в реконструкции отдельных улиц, внимательными родителя и, наконец, авангардом целого поколения, выросшего на органических продуктах.)

It makes sense to consider the notion gentrifier (gentrification) as referentially non-equivalent vocabulary according to the classification of A. Ivanov, as in the majority of explanatory dictionaries it is not available [1,2]. Only Multitran gives it a detailed explanation. In I. A. Sternin's opinion, it is one of the language gap characteristics (cultural lacuna) [3]. So we compensate the gap with "temporary means of language", by resorting to full explanation.

The author goes on to describe the main characters in the novel, the family Berglundov, hanging them on another label 'the avant-garde of the Whole Foods generation. Ignoring the barbarism at the beginning of the sentence, we are concentrated on American eagerness for organic products, mentioned by the author, using exoticism as a part of the attributive group. To compensate the lacuna, we resort to the descriptive translation.

Further, the author mentions a profession «lawyer in the field of environmental protection» which is not familiar to the Russian mentality, which can be attributed to the time-non-equivalent terms according to the classification of L. K. Latyshev [4, 5]. (Together with Walter-environmental lawyer, commuter cyclist, total family man ...). Using the calque and transcription/ transliteration «юрист-энвайронменталист» does not provide the necessary degree of comprehension, because there is great difference between our judicial systems. Therefore the explication with the commentary of the complex word as «юридическое лицо, регулирующее общественные отношения в сфере взаимодействия общества и природы» becomes the most successful option.

In the same sentence "commuter cyclist" draws our attention as it is relatively new and has not yet the phenomenon. That's why we can specify it as a structural exotism. For Russia, commuters who commute to the city by buses, trains, or planes are not unusual, but for the Russian people riding a bike for long distances seems strange enough. In order to overcome cultural barriers in the perception of such a notion and adopt it to our culture in translation, we present an extended explanation - «любитель добираться на работу на велосипеде». 
In the preface to the sentence "What exactly is Richard Katz-outré rocker and Walter's college best friend and rival-still doing in the picture?" (Кем же является Ричард Кати - рокером-бунтарем и лучшим другом Уолтера по колледжу или его соперником, все делающем напоказ?) we distinguish a lexeme relating to random non-equivalent vocabulary in the classification of $\mathrm{L}$. $\mathrm{K}$. Latyshev $[4,5]$. Borrowed by the English language, the semantic content of the lexeme has undergone major changes - the focus has shifted (exaggerated / exaggerated became secondary equivalents). And a new expressive denotative meaning was formed. Despite the unusual contextual environment, the unit transcoding is easy. The option "eccentric rocker" provides the necessary degree of cultural identity understanding.

Background vocabulary unit "Victorian" in the sentence "They paid nothing for their Victorian and then killed themselves for ten years renovating it." (Купив за гроши дом Викторианской эпохи, они еще десяток лет страдали от постоянных ремонтов), can be qualified as metonymy and we transcode it by the context expansion «дом Викторианской эпохи», in order to fill 'inferiority' elliptical design.

While translating, we notice a number of personal names (Walter, Patty, the Berglunds, Seth, Merrie, the Paulsens, Connie, Carol, Monaghan etc), which are transmitted by means of transcription (Walter, Patty, Merrie, Connie, Carol, Monaghan), transcription and adding (the Berglunds, the Paulsens) and traditional equivalent (Seth).

We have also identified a number of toponyms (St. Paul, Ramsey Hill, New York City, White Plains, Summit Avenue, Barrier Street). Dealing with them we appealed to different techniques - transcription (St. Paul, Ramsey Hill, New York City), transcription and translation (Summit Avenue, Barrier Street) and several different transformations in the case of White Plains, the names of companies (Big Coal), newspapers (New York Times) and non-governmental organizations (Greenpeace), we pass by means of transcription.

In the text space we have seen such American realia as Schlitz. Since not all recipients are familiar with the American breweries and distilleries traditions, varieties and brands of produced drinks, we are transcribing the name of the drink without adding extended comments, so as not to 'burden' the translation but giving a footnote to inform the reader that this brand of American beer has a long history.

Within the same sentence, we find another nationally-marked lexeme, a translation of which is not as simple as it might seem at first glance. "Sweat clothes", in essence, is a kind of warm tracksuit (relatively free cut), although in some contexts the combination can take the meaning "pajamas". The context tells us that getting out of the house in a tracksuit, when you are suddenly awaken in the wee hours, can be strange enough. For this reason we use a narrow contextual equivalent "pajamas".

The above paragraph also contains a translation difficulties caused by mother tongue interference. The author mentions connotative for the Russianspeaking recipient realia "string bags", which at first glance seems to be appropriately translated as «авоська». But, it would be a mistake. National differences in the content of close concepts from different cultural communities 
distort perception and the overall impression of readers as a version «авоська» as opposed to neutral «сетчатая сумка» evokes extensive associative array from the Russian-speaking recipients, which is the part of the cultural memory since the days of the Soviet Union era. To avoid these negative effects of "excessive" translation, and, consequently, the potential pragmatic changes, we should use a neutral variant «сетчатая сумка».

In the sentence "Behind her you could see the baby-encumbered preparations for a morning of baby-encumbered errands; ahead of her, an afternoon of public radio, the Silver Palate Cookbook, cloth diapers, drywall compound, and latex paint; and then Goodnight Moon, then zinfandel". (Позади были обременительные приготовления к рождению ребенка в рамках не менее обременительных утренних поручений, приуроченных к рождению ребенка, а впереди ее ожидал дневной эфир частной радиостанции, поваренная книга Сильвер Пэлэт (Букв. Серебряное нёбо), матерчатые подгузники, смесь сухой штукатурки, эмульсионная краска, и только потом, ближе к ночи, бокальчик зинфанделя), we find a great number of nationally-marked units.

In this sentence the author uses the nomination, addressing us to a cookbook, known in America as "The Silver Palate Cookbook". In Russian culture it is not typical to single out a definite cookbook. In America, on the contrary (probably because of the greater development of marketing and market relations) the most popular cook book - "The Silver Palate Cookbook", is sorted out. The fact that the book has had 25 publications signifies of its great popularity. So, the name of the book can be omitted.

In the same sentence, the author uses the exoticism "zinfandel", which is of interest for several reasons. Despite the fact that the sample is not a difficulty with the translation point of view, it is possible to transcribe exoticism and add a comment, informing the reader that this is a sort of Californian wine. There is a need to preserve the original linguo-pragmatic potential, as is exoticism is the precedent phenomenon. In the minds of every American there is a stereotype that Zinfandel is preferred by people who are not keen in on wines, but try to make that impression and look refined and pretentious. So that information can be commented.

In the text space we encounter a precedent phenomenon Volvo 240th model that says nothing to the Russian recipient. He can not understand why driving this car should cause embarrassment. For Americans on the contrary, it is quite obvious, as this automobile was very popular in eighties of the previous centuary.

In the fragment "The Berglunds were the super-guilty sort of liberals who needed to forgive everybody so their own good fortune could be forgiven" (Бэрглунды были этакими либералами с гигантским комплексом вины, которым требовалось простить всех, чтобы им простили немалое богатство), the author describes political views of the main characters, calling them liberals, which is a nationally-motivated difficulty for the translator because, as once P. R. Palazhchenko remarked, this concept is interpreted in different ways on both sides of the Atlantic, and in Russia, until recently, it was interpreted too ideologized [6]. For example, in the dictionary of S. I. Ozhegov (edition 1985) is defined as 1) the bourgeois ideological and political movement 
that brings together supporters of the parliamentary system and the limitations of the bourgeois-democratic freedoms; 2) excessive tolerance, forbearance, temporary indulgence. Returning to the difference between American and European varieties in the definition of this note, in Europe it means the commitment of a moderate democratic freedoms, and in the United States is focused on solving the problems of minorities, the fight against poverty and the regulation of economic processes using tools contradicting traditional liberal political doctrine [7]. Taking into account the difficulty of distinguishing additive shades meaning of two values - liberal in the sense of a generous, open and tolerant man and liberal connected with the liberal ideas in the American tradition, is reasonable to leave in the translation «либералы», to avoid ambiguity.

The author dilutes the story with the French realia in the world of wine produce - "Beaujolais nouveau". The «Божоле Нуво» translation is an adopted French inclusion.

Summing up it is worth mentioning that lacuna studying allows to verify nationally specified peculiarities in the semantic area and language world picture. The main means of lacuna elimination are compensation, pragmatic adaptation, lexico-semantic alterations, which help to cope with lacunas in intercultural communication.

\section{References}

1. Иванов, А. О. Английская безэквивалентная лексика и ее перевод на русский язык : учеб. пособие / А. О. Иванов. - Л. : Ленингр. гос. ун-т, 1985. - 95 с.

2. Иванов, А. О. Безэквивалентная лексика / А. О. Иванов. - СПб. : Тип. издва Санкт-Петерб. гос. ун-та, 2006. - 200 с.

3. Стернин, И. А. Лакуны и концепты / И. А. Стернин, З. Д. Попова, М. А. Стернина // Лакуны в языке и речи : сб. науч. тр. / Благовещенский гос. пед. ун-т ; под ред. Ю. А. Сорокина, Г. В. Быковой. - Благовещенск, 2003. - С. 205 - 233.

4. Латышев, Л. К. Курс перевода: Эквивалентность перевода и способы ее достижения : учебник / Л. К. Латышев. - М. : Междунар. отношения, 1981. -248 с.

5. Латышев, Л. К. Перевод: теория, практика и методика преподавания / Л. К. Латышев, А. Л. Семенов. - М. : ACADEMIA, 2003. - 192 с.

6. Палажченко, П. Р. Мой несистематический словарь. В 2 т. Т. 2. Из записной книжки переводчика / П. Р. Палажченко. - 10-е изд., стереотип. - М. : Р. Валент, 2012. -248 с.

7. Ожегов, С. И. Толковый словарь русского языка / С. И. Ожегов, Н. Ю. Шведова. - 4-е изд., доп. - М.: ООО ИТИ Технологии, 2006. - 944 с.

\section{References}

1. Ivanov A.O. Angliiskaya bezekvivalentnaya leksika i ee perevod na russkii yazyk (English non-equivalent vocabulary and its translation into Russian), Leningrad: Leningradskii gosudarstvennyi universitet, 1985, $95 \mathrm{p}$.

2. Ivanov A.O. Bezekvivalentnaya leksika (Non-equivalent vocabulary), St. Petersburg: Tipografiya izdatel'stva Sankt-Peterburgskogo gosudarstvennogo universiteta, 2006, $200 \mathrm{p}$.

3. Sternin I.A., Popova Z.D., Sternina M.A. Lakuny v yazyke i rechi (Lacuna in language and speech), Collection of scientific papers, Blagoveshchensk, 2003, pp. 205-233. 
4. Latyshev L.K. Kurs perevoda: Ekvivalentnost' perevoda i sposoby ee dostizheniya (Course of translation: translation equivalence and ways to achieve it), Moscow: Mezhdunarodnye otnosheniya, 1981, $248 \mathrm{p}$.

5. Latyshev L.K., Semenov A.L. Perevod: teoriya, praktika i metodika prepodavaniya (Translation: theory, practice and teaching methods), Moscow: ACADEMIA, 2003, $192 \mathrm{p}$.

6. Palazhchenko P.R. Moi nesistematicheskii slovar'. V 2 tomakh. Tom 2. Iz zapisnoi knizhki perevodchika (My unsystematic dictionary. In 2 vols. Vol. 2. From the notebook of a translator), Moscow: R. Valent, 2012, 248 p.

7. Ozhegov S.I., Shvedova N.Yu. Tolkovyi slovar' russkogo yazyka (Dictionary of Russian language), Moscow: OOO ITI Tekhnologii, 2006, 944 p.

\section{Способы передачи межкультурной ассиметрии: познавательный и транскодирующий аспекты}

\section{В. А. Лазарев, М. В. Ласкова, М. С. Медведева}

ФГАОУ ВПО «Южный федеральный университет», 2. Ростов-на-Дону

Ключевые слова: безэквивалентный словарный запас; временнобезэквивалентные термины; культурная лакуна; национально-маркированная лексика; облагораживание; структурный экзотизм; транскрипция / транслитерация.

Аннотация: Выявлены способы преодоления межкультурных коммуникативных несоответствий при переводе художественных текстов. Уделено внимание вопросам достижения эквивалентности вторичного текста, осложненного когнитивными лакунами.

(C) В. А. Лазарев, М. В. Ласкова, М. С. Медведева, 2015 